\title{
UU NO 6 TAHUN 2014 TENTANG DESA SEBAGAI MANIFESTASI PENEGAKAN PASAL 18 B AYAT (2) UUD NRI TAHUN 1945
}

\author{
Amalia Diamantina \\ Fakultas Hukum Universitas Diponegoro \\ Jl. Prof. Soedarto, SH Tembalang Semarang \\ Email: amaliadiamantina.undip@gmail.com
}

\begin{abstract}
Article 18 B paragraph 2 of Indonesian Constitution states that the state recognize and respect the indigenous people with their indigenous rights as long as it is still alive with the society development and the state principle. The Act No. 6 of 2014 about village is the important moment in village regulation and it's progress, because this Act regulate more comprehensif than the previous Act. The Act is stated that the aim of vilage regulation is to recognize and respect to the vilages with various diversity which they have been before and after the independence of this state, and give status explication and legal certainty of vilages in Indonesia.
\end{abstract}

Keywords: Act No 6 of 2014; Admission of Indigenous People.

\begin{abstract}
Abstrak
Pasal 18 B ayat (2) UUD NRI menyatakan bahwa negara mengakui dan menghormati kesatuankesatuan masyarakat hukum adat beserta hak hak tradisionalnya sepanjang masih hidup dan sesuai dengan perkembangan masyarakat dan prinsip NKRI. Diundangkannnya UU No 6/ 2014 tentang Desa merupakan momen penting dalam perkembangan pengaturan desa dan kemajuan desa, hal ini disebabkan karena UU No 6 Tahun 2014 mengatur Desa secara lebih komprehensif bila dibandingkan dengan pengaturan didalam undang undang yang ada sebelumnya. UU No 6/2014 sebagaimana disebutkan dalam penjelasan umumnya menyatakan bahwa tujuan pengaturan desa antara lain adalah untuk memberikan pengakuan dan penghormatan atas desa yang sudah ada dengan keberagamannya sebelum dan sesudah terbentuknya NKRI serta memberikan kejelasan status dan kepastian hukum atas desa dalam sistem ketatanegaraan RI.
\end{abstract}

Kata Kunci: UU No. 6 Tahun 2014; Pengakuan terhadap Kesatuan Masyarakat Hukum Adat.

\section{A. Pendahuluan}

Sejarah panjang mengenai keberadaan dan pengaturan desa dalam NKRI dapat ditelusuri sejak masa sebelum kemerdekaan, masa kolonial, masa kemerdekaan dengan beberapa periodesasi yaitu masa pasca kemerdekaan, masa orde lama, masa orde baru, masa reformasi sampai diundangkannya UUNo. 6 Tahun 2014 tentang Desa. Pengaturan mengenai Desa dari masa kolonial hingga saat ini selalu berada dalam pusaran kepentingan politik para elit negara. ${ }^{2}$

Pada masa reformasi terdapat 2 undang-undang yang mengatur mengenai kesatuan masyarakat hukum adat atau desa, berdasarkan Pasal 18 UUD Tahun 1945 yaitu
UU No. 22 Tahun 1999 tentang Pemerintahan Daerah yang berlaku sampai diundangkannnya UU No. 32 Tahun 2004 tentang Pemerintahan Daerah, yang disusun berdasarkan Pasal 18 Undang-Undang Dasar Negara Republik Indonesia Tahun 1945 (UUD NRI Tahun1945). Menurut Ni'matul Huda kesatuan masyarakat hukum adat atau desa dalam kedua undang -undang ini seolah menemukan jati diri sebagai entitas yang hidup dalam masyarakat, karena adanya pengakuan negara terhadap eksistensi kesatuan masyarakat hukum adat yang terkubur selama Orde Baru. Namun demikian dengan adanya kekurangan dalam UU No. 22 tahun 1999 baik dalam mengatur

\footnotetext{
1. Ni'matul Huda, 2015, Hukum Pemerintahan Desa, Malang, Setara Pers, hlm 2-3.

2. Ibid, hlm xii

3. Ibid, hlm ix
} 
pemerintahan daerah maupun pemerintahan desa maka MPR mengeluarkan suatu rekomendasi dengan Ketetapan MPR No.IV /MPR/2000 tentang Rekomendasi dalam Penyelenggaraan Otonomi Daerah. Salah satu butir rekomendasi dalam Ketetapan tersebut menyatakan bahwa sejalan dengan semangat desentralisasi, demokrasi dan kesetaraan hubungan pusat dan daerah diperlukan upaya perintisan awal untuk melakukan revisi yang bersifat mendasar terhadap UU No. 22 Tahun 1999 tentang Pemerintahan Daerah. Bersamaan dengan itu dalam Sidang Tahunan MPR RI Tahun 2000 telah dilakukan Perubahan Kedua UUD 1945 yang merubah Bab Vl tentang Pemerintahan Daerah dengan menyempurnakan Pasal 18 menjadi Pasal 18, Pasal 18 A, dan Pasal 18 B. Pada Pasal 18 B ayat (2) UUDNRI Tahun 1945 dinyatakan bahwa negara mengakui dan menghormati kesatuan-kesatuan masyarakat hukum adat beserta hak hak tradisionalnya sepanjang masih hidup dan sesuai dengan perkembangan masyarakat dan prinsip Negara Kesatuan Republik Indonesia. Berdasar pasal tersebut dan Pasal $18 \mathrm{~B}$ ayat (7) UUD NRI Tahun 1945 maka diundangkanlah UU No.32 Tahun 2004 tentang Pemerintahan Daerah. Pengaturan tentang pemerintahan desa di dalam UU No. 32 Tahun 2004 tidak memperlihatkan perubahan yang berarti atau tidak menimbulkan perubahan yang prinsipiil. Berdasarkan uraian di atas, maka penting adanya kajian tentang bagaimana UU No. 6 Tahun 2014 tentang Desa mengakomodir dan memberi kepastian hukum terhadap keberadaan kesatuan masyarakat hukum adat beserta hak hak tradisionalnya sehingga UU No. 6 Tahun 2014 dapat dikatakan sebagai undang-undang yang menegakkan Pasal $18 \mathrm{~B}$ ayat(2)UUDNRI Tahun 1945.

\section{B. Pembahasan}

UU No. 6 Tahun 2014 tentang Desa, yang lahir di tahun politik, sangat mungkin menjadi komoditas politik, karena melalui UU Desa partai partai politik ingin meraup suara pemilih di pedesaan, sehingga tuntutan masyarakat dan aparatur desa dapat terakomodir didalamnya, partai partai bersaing mencari simpati masyarakat di desa dengan mengkampanyekan bahwa UU Desa adalah buah perjuangan partai-partai tersebut. Dan menjadi wajar kalau kemudian perangkat desa segera menutut janji kampanye tersebut diemplementasikan pada tahun 2015. Terlepas dari pertarungan politik dalam Pemilu 2014, dengan lahirnya UU No. 6 Tahun 2014 masyarakat di desa telah mendapatkan payung hukum yang lebih kuat dibandingkan pengaturan desa di dalam UU No. 22 tahun 1999 maupun UU No. 32 Tahun 2004. Walaupun tidak dapat dinafikan, bahwa pandangan masyarakat terhadap UU Desa tersebutlebih besar tertuju kepada alokasi dana desa yang sangat besar, ${ }^{6}$ namun demikian sebenarnya isi dari UU Desa meliputi hal hal yang cukup luas.

Pasal 18 B ayat (2) sebagai dasar diundangkannya UU No. 6 Tahun 2014 tentang Desa menyatakan :

Negara mengakui dan menghormati satuan-satuan masyarakat hukum adat beserta hak-hak tradisionalnya sepanjang masih hidup dan sesuai dengan perkembangan masyarakat dan prinsip negara kesatuan NKRI yang diatur dalam undang-undang.

Di dalam pasal ini sama sekali tidak disebutkan tentang Desa, maupun pemerintahan desa, yang disebutkan hanya kesatuan masyarakat hukum adat dan hak hak tradisional. Namun demikian menurut Pasal 1 angka (1) UU Desa:

"desa dan desa adat atau yang disebut dengan nama lain, selanjutnya di sebut desa adalah kesatuan masyarakat hukum yang memiliki batas wilayah yang berwenang untuk mengatur dan mengurus urusan pemerintahan, kepentingan masyarakat setempat berdasarkan pakarsa masyarakat, hak asal usul, dan/atau hak tradisional yang diakui dan dihormati dalam sistem pemerintahan Negara Kesatuan Republik Indonesia”.

Dari pernyataan pasal ini dapat

4. Ibid, hlm 185

5. Mashuri Maschab, 2013, Politik Pemerintahan Desa di Indonesia, Cet I, Yogyakarta, PolGov Fisipol UGM, hlm 146.

${ }^{6}$ Ni'matul Huda, Op.Cit, hlm 206-207. 
dijelaskan bahwa UU Desa menyebutkan, bahwa Desa adalah desa dan desa adat atau yang disebut dengan nama lain. Desa dan Desa Adat atau yang disebut dengan nama lain merupakan kesatuan masyarakat hukum. Dalam kaitannya dengan Pasal 18 B ayat (2) maka ada kesatuan masyarakat hukum adat yang masih memiliki hak hak tradisional nya yang masih hidup dan berkembang sesuai dengan perkembangan masyarakat dan prinsip NKRI yang harus diakui dan dihormati.

Selanjutnya di dalam Penjelasan Umum UU Desa juga dinyatakan bahwa dengan konstruksi menggabungkan selfgoverning community dengan local self government, diharapkan kesatuan masyarakat hukum adat yang selama ini menjadi bagian dari wilayah Desa, ditata sedemikian rupa menjadi Desa dan Desa Adat. Desa dan Desa Adat pada dasarnya melakukan tugas yang hampir sama. Sedangkan perbedaannya hanyalah dalam pelaksanaan hak asal usul, terutama menyangkut pelestarian sosial Desa Adat, pengaturan dan pengurusan wilayah adat, sidang perdamaian adat, pemeliharaan dan ketertiban bagi masyarakat hukum adat, serta pengaturan pelaksanaan pemerintahan berdasar susunan asli.

Desa Adat memiliki fungsi pemerintahan, keuangan Desa, serta mendapat fasilitas dan pembinaan dari pemerintah Kabupaten/Kota. Dalam posisi seperti ini Desa dan Desa Adat mendapat perlakuan yang sama dari Pemerintah dan Pemerintah Daerah. Oleh sebab itu di masa depan Desa dan Desa Adat dapat melakukan perubahan wajah Desa dan tata kelola penyelenggaraan pemerintahan yang efektif, pelaksanaan pembangunan yang berdaya guna, serta pembinaan masyarakat dan pemberdayaan masyarakat di wilayahnya. Dalam status yang sama seperti ini, Desa dan Desa Adat diatur secara tersendiri di dalam undang undang ini.

Menurut Pasal 6 UU Desa, jenis desa terdiri dari Desa dan Desa Adat, penyebutan Desa atau Desa Adat disesuaikan dengan penyebutan yang berlaku di daerah setempat. Desa atau yang disebut dengan nama lain mempunyai karakteristik yang berlaku umum untuk seluruh Indonesia, sedangkan Desa Adat atau yang disebut dengan nama lain mempunyai karakteristik yang berbeda dari Desa pada umumnya, terutama karena kuatnya pengaruh adat terhadap sistem pemerintahan lokal, pengelolaan sumber daya lokal, dan kehidupan sosial budaya masyarakat Desa.

Desa Adat pada prinsipnya merupakan warisan organisasi kepemerintahan masyarakat lokal yang dipelihara secara turun -temurun yang tetap diakui dan diperjuangkan oleh pemimpin dan masyarakat Desa Adat agar dapat berfungsi mengembangkan kesejahteraan dan identitas sosial budaya lokal. Desa Adat memiliki hak asal usul yang lebih dominan daripada hak asal usul Desa sejak Desa Adat itu lahir sebagai kominitas asli yang adadi tengah masyarakat. Desa Adat adalah sebuah kesatuan masyarakat hukum adat yang secara historis mempunyai batas wilayah dan identitas budaya yang terbentukatas dasar teritorial yang berwenang mengatur dan mengurus kepentingan masyarakat Desa hak asal usul. Pada dasarnya kesatuan masyarakat hukum adat terbentuk berdasarkan tiga prinsip dasar, yaitu genealogis, teritorial, dan/atau gabungan genealogis degna teritorial, yang dimaksud dalam UU Desa adalah kesatuan masyarakat hukum adat yang merupakan gabungan antara genealogis dan teritorial. Dalam kaitannnya itu, negara mengakui dan menghormati kesatuan masyarakat hukum adat beserta hak tradisionalnya sepanjang masih dan sesuai dengan perkembangan masyarakat dan prinsip Negara Kesatuan Republik Indonesia. Implementasi dari kesatuan masyarakat hukum adat tersebut telah ada dan hidup di wilayah Negara Kesatuan Republik Indonesia, seperti huta/nagori di Sumatera Utara, gampong di Aceh, nagari di Minangkabau, marga di Sumatera bagian Selatan, tiuh atau pekon di lampung, desa pakraman/desa adat di Bali, lembang di Toraja, banua dan wanua di Kalimantan, dan negeri di Maluku. ${ }^{7}$

Penetapan Desa Adat untuk pertama

\footnotetext{
7. Lastuti Abubakar, "Revitalisasi Hukum Adar Sebagai Sumber Hukum Dalam Membangun Sistem Hukum Indonesia”, Jurnal Dinamika Hukum, Vol. 11, No. 2, Mei 2013, hlm. 319-331.
} 
kalinya berpedoman pada ketentuan khusus sebagaimana diatur dalam Bab XIII UU Desa, sedangkan pembentukan Desa Adat yang baru berpedoman pada ketentuan sebagaimana diatur dalam Bab III UU Desa. Beberapa Putusan Mahkamah Konstitusi juga manjadi acuan utama dalam penetapan Desa Adatyaitu:

1. Putusan No.010/PUU-1/2003 perihal Pengujian Undang Undang No.53 tahun 11 tahun 2003 tentang Perubahan Atas Undang-Undang No. 53 tahun 1999 tentang Pembentukan Kabupaten Pelalawan, Kabupaten Rokan Hulu, Kabupaten Rokan Hilir, Kabupaten Natuna, Kabupaten Kuantan Singingi dan Kota Batam.

2. Putusan No. 31/PUU-V/2007/ perihal Pengujian Undang Undang No. 31 tahun 2007 tentang Pembentukan Kota Tual di Provinsi Maluku.

3. Putusan No. 6/PUU-VI/2008 perihal PengujianUndang Undang No. 51 tahun 1999 tentang Pembentukan Kabupaten Buol, Kabupaten Morowali, dan KabupatenBanggai Kepulauan

4. Putusan no. 35/PUU-X/2012 perihal Pengujian Undang Undang no.41 tahun 1999 tentang Kehutanan.

Namun demikian karena kesatuan masyarakat hukum adat yang ditetapkan menjadi Desa Adat melaksanakan fungsi pemerintahan (local self government )maka ada syarat mutlak yaitu adanya wilayah dengan batas yang jelas, adanya pemerintahan, dan perangkat lain serta ditambah dengan salah satu pranata lain dalam kehidupan masyarakat hukum adat seperti perasaan bersama, harta kekayaan, dan pranata pemerintahan adat.

Dalam UU Desa diatur mengenai kelembagaan Desa/Adat yaitu lembaga Pemerintahan Desa/Adat, yang terdiri atas Pemerintah Desa/Desa Adat, Badan Permusywaratan Desa/Desa Adat, Lembaga Kemasyarakatan Desa, dan lembaga Adat. Pemerintah dan masyarakat Desa dapat membentuk lembaga adat Desa. Lembaga adat Desa merupakan lembaga yang menyelenggarakan fungsi adat istiadat dan menjadi bagian dari susunan asli Desa yang tumbuh dan berkembang atas prakarsa masyarakat Desa. Lembaga adat Desa betugas membantu Pemerintah Desa dan sebagai mitra dalam memberdayakan, melestarikan, dan mengembangkan adat istiadat sebagai wujud pengakuan terhadap adat istiadat masyarakat Desa. ${ }^{8}$

Kepala Desa/Desa Adat atau yang disebut dengan nama lain merupakan kepala Pemerintahan Desa/Desa Adat yang memimpin Pemerintahan Desa. Selanjutnya sebutan kepala Desa/desa Adat yang berkedudukan sebagai pemimpin masyarakat disesuaikan dengan sebutan lokal, sedangkan mengenai pengisian jabatannya bagi kepala Desa Adat dapat menggunakan mekanisme lokal, yaitu berlaku ketentuan hukum adat di Desa Adat sepanjang masih hidup dan sesuai dengan perkembangan masyarakat serta prinsip Negara Kesatuan Republik Indonesia yang ditetapkan dalam Peraturan Daerah Kabupaten/Kota dengan berpedoman pada Peraturan Pemerintah. Demikian pula apabila terjadi kekosongan jabatan kepala Desa Adat, maka pemerintah Daerah Kabupaten/Kota dapat menetapkan penjabat yang berasal dari masyarakat Desa Adat yang bersangkutan.

Badan Permusyawaratan Desa atau yang disebut dengan nama lain adalah lembaga yang melakukan fungsi pemerintahan yang anggotanya merupakan wakil dari penduduk desa berdasarkan keterwakilan wilayah dan ditetapkan secara demokratis. Badan ini merupakan badan permusyawaratan tingkat desa yang turut membahas dan menyepakati berbagai kebijakan dalam penyelenggaraan Pemerintahan Desa dalam upaya meningkatkan kinerja kelembagaan tingkat desa, memperkuat kebersamaan serta meningkatkan partisipasi dan pemberdayaan masyarakat, pemerintah Desa dan/atau badan Permusyawaratan Desa memfasilitasi peneyelenggaraan Musyawarah Desa. Musyawarah Desa atau yang disebut dengan nama lain adalah forum musyawarah antara

8. Renny H. Nendisa,"Eksistensi Lembaga Adat Dalam Pelaksanaan Hukum Sasi Laut Di Maluku Tengah”, Jurnal Sasi,

Vol. 15, No. 4, Oktober-Desember 2010, hlm 3.

9. Emilda Firdaus, "Badan Permusyawarahan Desa Dalam Tiga Periode Pemerintahan Di Indonesia", Jurnal Ilmu Hukum, Vol. 2, No. 2, 2011, hlm 16 
Badan Permusyawaratan Desa, Pemerintah Desa, dan unsur masyarakat yang dis elenggarakan oleh Badan Permusyawaratan Desa untuk memusyawarahkan dan menyepakati hal yang bersifat strategis dalam penyelenggaraan Pemerintahan Desa. Hasil Musyawarah Desa dalam bentuk kesepakatan yang dituangkan dalam keputusan hasil musyawarah dijadikan dasar oleh Badan Permusyawaratan Desa dan Pemerintah Desa dalam menetapkan kebijakan Pemerintahan Desa. Dalam hubungannya dengan hal tersebut Naeni Amanulloh menyebutnya sebagai Lembaga-lembaga Demokrasi Desa. ${ }^{10}$

Berdasarkan Pasal-96 dan Pasal 97 UU Desa, penataan kesatuan masyarakat hukum adat dilakukan oleh Pemerintah, Pemerintah Daerah Provinsi, Pemerintah daerah Kabupaten/Kota untuk dapat ditetapkan nmenjadi Desa Adat. Penetapan Desa Adat sebagaimana dimaksud harus memenuhi syarat sebagai berikut;

1. Kesatuan masyarakat hukum adat besrta hak tradisionalnya secara nyata masih hidup, baik yang bersifat teritorial, genealogis, maupun yang bersifat fungsional, dlam hal ini harus memiliki wilayah dan paling kurang memenuhi salah satu atau gabungan unsur adanya: a).Masyarakat yang warganya memiliki perasaan bersama dalam kelompok; b). Pranata pemerintahan adat; c).Harta kekayaan dan/atau benda adat, dan d).perangkat norma hukum adat.

2. Kesatuan masyarakat hukum adat beserta hak tradisionalnya dipandang sesuai dengan perkembangan masyarakat, apabila a). Keberadaannya telah dakui berdasarkan undang - undang yang berlaku sebagai pencerminan perkembangan nilai yang dianggap ideal dalam masyarakat dewasa ini, baik undang-undang yang bersifat khusus maupun bersifat sektoral; b). Substansi hak tradisional tersebut diakui dan dihormati oleh warga kesatuan masyarakat yang bersangkutan dan masyarakat yang lebih luas serta tidak bertentangan dengan hak asasi manusia.

3. Kesatuan masyarakat hukum adat beserta hak tradisionalnya sesuai dengan prinsip Negara Kesatuan Republik Indonesia, sebagai sebuah kesatuan politik dan kesatuan hukum; a). Tidak mengancam kedaultan dan integritas Negara Kesatuan Republik Indonesia, b). Substansi norma hukum adatnya sesuai dan tidak bertentangan dengan ketentuan perauran perundangundangan.

Berdasarkan Pasal 103 UU Desa hak asal usul meliputi:

Lebih lanjut di dalam Penjelasan Umum UU Desa dinyatakan bahwa asas pengaturan undang undang ini adalah:

a. Pengaturan dan pelaksanaan pemerintahan berdasarkan susunan asli.

b. Pengaturan dan pengurusan ulayat atau wilayah adat.

c. Pelestarian nilai sosial budaya desa adat.

d. Penyelesaian sengketa adat berdasarkan hukum adat yang berlaku di Desa Adat dalam wilayah yang selaras prinsip hak asasi manusia dengan mengutamakan penyelesaian secara musyawarah.

e. Penyelenggaraan sidang perdamaian peradilan Desa Adat sesuai dengan ketentuan perundang-undangan.

f. Pemeliharaan ketentraman dan ketertiban masyarakat Desa Adat berdasarkan hukum Adat yang berlaku di Desa Adat.

g. Pengembangan kehidupan hukum adat sesuai dengan kondisi sosial budaya masyarakat Desa Adat.

Menurut penjelasan umum UU Desa, tujuan pengaturan Desa adalah;

1. Memberi pengakuan dan penghormatan atas Desa yang sudah ada dengan keberagamannya sebelum dan sesudah terbentuknya NKRI.

2. Memberikan kejelasan status dan kepastian hukum atas Desa dalam sistem ketatanegaraan RI demi mewujudkan keadilan seluruh rakyat Indonesia.

3. Melestarikan dan memajukan adat, tradisi, dan budaya masyarakat Desa.

4. Mendorong prakarsa, gerakan, dan

\footnotetext{
10.Naeni Amanulloh, 2015, Demokratisasi Desa, Jakarta, Kementerian Desa PDT dan Transmigrasi, hlm 23.
} 
partisipasi masyarakat Desa untuk pengembangan potensi dan aset Desa guna kesejahteraan bersama

5. Membentuk Pemerintahan Desa yang profesional, efisien dan efektif, terbuka, serta bertanggung jawab.

6. Meningkatkan pelayanan publik bagi warga masyarakat Desa guna mempercepat perwujudan kesejahteraan umum.

7. Meningkatkan ketahanan sosial budaya masyarakat Desa guna mewujudkan masyrakat Desa yang mampu memelihara kesatuan sosial sebagai sebagai bagian dari ketahanan nasional.

8. Memajukan perekonomian masyarakat Desa serta mengatasi kesenjangan pembangunan nasional.

9. Memperkuat masyarakat Desa sebagai subyek pembangunan.

Lebih lanjut di dalam Penjelasan Umum

UU Desa dinyatakan bahwa asas pengaturan undang undang ini adalah:

1. Rekognisi, yaitu pengakuan terhadap hak asal usul.

2. Subsidaritas, yaitu penetapan kewenangan berskal lokal dan pengambilan keputusan secara lokal untuk kepentingan masyarakat Desa.

3. Keberagaman, yaitu pengakuan dan penghormatan terhadap sistem nilai yang berlaku di masyarakat Desa, tetapi dengan tetap mengindahkansistem nilai bersama dalam kehidupan berbangsa dan bernegara.

4. Kebersamaan, yaitu semangat untuk berperan aktif dan bekerja sama dengan prinsip saling menghargai antara kelembagaan di tingkat Desa dan unsur masyarakat Desa dalam membangun Desa.

5. Kegotong-royongan, yaitu kebiasaan saling tolong-menolong untuk membangun Desa

6. Kekeluargaan, yaitu kebiasaan warga masyarakat Desa sebagai bagian darisatu kesatuan keluarga besar masyarakat Desa.

7. Musyawarah, yaitu proses pengambilan keputusan yang menyangkut kepentingan masyarakat Desa melalui diskusi dengan berbagai pihak yang berkepentingan.

8. De mokrasi, yaitu sistem pengorganisasian masyarakat Desa dalam suatu sistem pemerintahan yang dilakukan oleh masyarakat Desa serta keluhuran harkat dan martabat manusia sebagai makhluk Tuhan Yang Maha Esa diakui, ditata, dan dijamin.

9. Kemandirian, yaitu suatu proses yang dilakukan oleh Pemerintah Desa dan Masyarakat Desa untuk melakukan suatu kegiatan dalam rangka memenuhi kebutuhannya dengan kemampuan sendiri.

10. Partisipasi, yaitu turut berperan aktif dalam suatu kegiatan

11. Kesetaraan, yaitu kesamaan dalam kedudukan dan peran.

12. Pemberdayaan, yaitu upaya meningkatkan taraf hidup dan kesejahteraan masyarakat Desa melalui penetapan kebijakan, program, dan kegiatan yang sesuai dengan esensi masalah dan prioritas kebutuhan masyarakat Desa.

13. Keberlanjutan, yaitu suatu proses yang dilakukan secara terkoordinasi, terintegrasi, dan berkesinambungan $\mathrm{da} l \mathrm{a} m$ merencanakan dan melaksanakan program pembangunan desa.

Berdasarkan hal tersebut diatas nampak bahwa melalui UU Desa, pemerintah berusaha untuk memberikan kejelasan status Desa dan Desa Adat dengan berbagai keberagamannya di Indonesia. Hal ini dikarenakan implementasi kebijakan desa selama ini masih bertumpu pada pemerintahan desa yang menerima pelimpahan tugas/wewenang dari pusat atau kabupaten, tanpa memperlihatkan kekhususan atau desentralisasi-simetrik terhadap desa-desa yang masih memegang teguh pelaksanaan tradisi, kebiasaan dan hukum adat. ${ }^{11}$ Implementasi kebijakan desa yang sentralistik disatu sisi dianggap

11. M. Syamsudin,'Beban Masyarakat Adat Menghadapi Hukum Negara”, Jurnal Hukum Ius Quia Iustum, Vo. 15 No. 3, Juli 2008, hlm. 338-351. 
bertopang kepada kebudayaan lokal, tetapi disisi lain landasan material-spiritualnya dibiarkan binasa, Kelembagaan adat di desa belum tersusun secara khusus (desentralisasi asimetrik0, sehingga pemerintah tidak mengetahui aset-aset penghidupan (livelihood assets). ${ }^{12}$

Pengaturan desa dalam UU Desa menciptakan posisi baru dan relasi baru antara negara dengan warga negara, dimana negara melalui UU Desa telah melakukan rekognisi (pengakuan dan penghormatan) terhadap eksistensi desa. Negara memberikan atau menetapkan mandat urusan pemerintahan dan kepentingan masyrakat setempat kepada desa, negara melakukan redistribusi berupa uang dan sebagian aset negara, selain itu negara melakukan pembinaan, pemberdayaan dan pengawasan terhadap Desa. Pada sisi yang lain bagi warga negara, desa menjadi basis sosial bagi warga masyarakat, menjadi arena untuk merajut modal sosial. ${ }^{13}$ Desa menjadi arena politik dan pemerintahan bagi warga, desa menjadi arena perencanaan dan penganggaran secra kolektif dan partisipatif. Desa memberikan pelayanan dasar kepada warga dan melakukan konsolidasi aset ekonomi lokal. ${ }^{14}$

Kedudukan (posisi) desa dalam bangunan besar tata negara Indonesia, sekaligus relasi antara negara, desa dan warga Negara merupakan jantung persoalan UU Desa. ${ }^{15}$ Paradigma yang mengkonstruksi hubungan negara dan desa yaitu rekognisi dan subsidaritas. Rekognisi terhadap Desa yang dilembagakan dalam UU Desa bersifat kontekstual, konstitusional, dan merupakan hasil negosiasi politik yang panjang antara
Pemerintah, DPR, DPD, dan Desa. Sesuai amanat konstitusi maka kita semua wajib melakukan pengakuan dan penghormatan terhadap keberadaan (eksistensi) desa sebagai kesatuan masyarakat hukum. ${ }^{16}$ Eksistensi Desa dalam hal ini mencakup hak asal usul wilayah, pemerintahan, peraturan maupun pranata lokal, lembaga lembaga lokal, identitas budaya, kesatuan masyarakat, prakarsa desa, maupun kekayaan desa. Subsidaritas adalah lokalisasi penggunaan kewenangan dan pengambilan keputusan tentang kepentingan masyarakat setempat kepada Desa. ${ }^{18}$

Kombinasi antara asas rekognisi dan subsidaritas, UU Desa menghasilkan definisi desa yang berbeda dengan definisi definisi sebelumnya. Desa didefinisikan sebagai masyarakat hukum yang memiliki batas wilayah yang berwenang mengatur dan mengurus urusan pemerintah, kepentingan masyarakat setempat berdasarkan prakarsa masyarakat, hak asal usul, dan/atau hak tradisional yang diakui dan dihormati dalam sistem pemerintahan NKRI. Dengan definisi tersebut UU Desa telah menempatkan desa sebagai organisasi campuran (hybrid) antara masyarakat berpemerintahan (self governing community) dengan pemerintahan lokal (local self government)..$^{19}$ Dengan begitu, sistem pemerintahan di Desa berbentuk pemerintahan masyarakat atau pemerintahan berbasis masyarakat dengan segala kewenangannnya (authorithy). ${ }^{20}$

\section{Simpulan}

Berdasarkan uraian di atas, dapat disimpulkan bahwa UU No. 6 Tahun 2014

12. Anom Surya Putra, 2015, Profesionalitas dan Kebijakan UUDesa, Jakarta,PMD Kemendagri, hlm 3.

13. Sadu Wasistiono, "Telaah Kritis Terhadap Rancangan Undang-undang Desa", Jurnal Ilmu Pemerintahan, MIPI, Edisi 38, hlm. 28.

14. Kementerian Desa PDT dan Transmigrasi, 2015, Regulasi Baru, Desa Baru, Bahan Sosialisasi, Jakarta, Kemeterian Desa PDT dan Transmigrasi, hlm 45.

15. Sutoro Eko, 2015, Regulasi Baru, Desa Baru, Ide Misi dan Semangat UU Desa, Jakarta, Kementerian Desa PDT dan Transmigrasi, hlm 32.

16. Sutrisno Purwohadi Mulyono, "Sinergitas Penyelenggaraan Pemerintahan Desa Pasca Pemberlakuan UU No. 6 Tahun 2014 Tentang Desa”, Jurnal Masalah-Masalah Hukum, Vol. 43, No. 3, Juli 2014, hlm. 438-444.

17. Ibid, hlm 40 .

18. Ibid, hlm 43 .

19. Utang Suwaryo, "Mengembalikan Otonomi Untuk Desa", Jurnal Pascasarjana, Governance, Vol. 2, No. 1, November 2011.

20. M. Silahuddin, 2015,Kewenangan Desa dan Regulasi Desa, Jakarta, Kementerian Desa PDT dan Transmigrasi,hlm 11. Lihat juga Mochammad Zaini Mustakim, 2015, Kepemimpinan Desa, Jakarta, Kementerian Desa PDT dan Transmigrasi, hlm 11. 
tentang Desa yang secara yuridis konstitusional didasarkan pada Pasal 18 D ayat (2) UUD NRI Tahun 1945 telah memberikan definisi baru tentang desa sebagai kesatuan masyarakat hukum yang diakui hak asal usul dan/atau hak tradisonalnya. Penggunaan asas rekognisi dan asas subsidaritas beserta pengaturannya menunjukkan bahwa UU No. 6 Tahun 2014 tentang Desa telah memberikan kejelasan status dan kepastian hukum atas keberadaan dan keberagaman Desa yang ada di Indonesia.

\section{Daftar Pustaka}

Abubakar Lastuti, "Revitalisasi Hukum Adar Sebagai Sumber Hukum Dalam Membangun Sistem Hukum Indonesia", Jurnal Dinamika Hukum, Vol. 11, No. 2, Mei 2013.

Amanulloh Naeni, 2015, Demokratisasi Desa, Jakarta, Kementerian Desa PDT dan Transmigrasi.

Eko Sutoro, 2015, Regulasi Baru, Desa Baru, Ide Misi dan Semangat UU Desa, Jakarta, Kementerian Desa PDT dan Transmigrasi.

Firdaus Emilda, "Badan Permusyawarahan Desa Dalam Tiga Periode Pemerintahan Di Indonesia", Jurnal Ilmu Hukum, Vol. 2, No. 2, 2011.

Huda Ni'matul , 2015, Hukum Pemerintahan Desa, Malang,Setara Press.

Kementerian Desa PDT dan Transmigrasi, 2015, Regulasi Baru, Desa Baru, Bahan Sosialisai UU No. 6/2014, Jakarta, Kementerian Desa PDT dan Transmigrasi.

Maschab Mashuri, 2013 , Politik Pemerintahan Desa di Indonesia, Cet I, Yogyakarta, PolGov Fisipol UGM.

Mustakim Mochammad Zaini, 2015, Kepemimpinan Desa, Jakarta, Kementerian Desa PDT dan Transmigrasi.

Mulyono Sutrisno Purwohadi, "Sinergitas Penyelenggaraan Pemerintahan Desa Pasca Pemberlakuan UU No. 6 Tahun 2014 Tentang Desa", MasalahMasalah Hukum, Vol. 43, No. 3, Juli 2014.

Nendisa Renny H.,'Eksistensi Lembaga Adat Dalam Pelaksanaan Hukum Sasi Laut
Di Maluku Tengah", Jurnal Sasi, Vol. 15, No. 4, Oktober-Desember 2010.

Putra, Anom Surya, 2015, Profesionalitas dan Kebijakan UU Desa, Jakarta, PMD Kemendagri.

Syamsudin M.,'Beban Masyarakat Adat Menghadapi Hukum Negara", Jurnal Hukum Ius Quia Iustum, Vol. 15, No. 3, Juli 2008.

Suwaryo Utang, "Mengembalikan Otonomi Untuk Desa", Jurnal Pascasarjana, Governance, Vol. 2, No. 1, November 2011.

Silahuddin M., 2015, Kewenangan Desa dan Regulasi Desa, Jakarta, Kementerian Desa PDT dan Transmigrasi.

Wasistiono Sadu, "Telaah Kritis Terhadap Rancangan Undang-undang Desa”, Jurnal Ilmu Pemerintahan, MIPI, Edisi 38 . 